\title{
Evaluation of Indoor Radiation Hazard on Worker \& Public Health in Mitford Hospital, Dhaka, Bangladesh
}

\author{
Md. Ahshan Habib ${ }^{1}$, Mohammad Sohelur Rahman ${ }^{2 *}$, Pretam Kumar Das ${ }^{1}$, Shudeb Kumar Roy ${ }^{1}$, Selina Yeasmin ${ }^{2}$
}

${ }^{1}$ Department of Physics, Pabna University of Science and Technology, BANGLADESH

${ }^{2}$ Health Physics Division, Atomic Energy Centre Dhaka-1000, BANGLADESH

*Corresponding Author: msrahman74@gmail.com

Citation: Habib, Md. A., Rahman, M. S., Das, P. K., Roy, S. K. and Yeasmin, S. (2021). Evaluation of Indoor Radiation Hazard on Worker \& Public Health in Mitford Hospital, Dhaka, Bangladesh. European Journal of Environment and Public Health, 5(1), em0061. https://doi.org/10.29333/ejeph/8576

\section{ARTICLE INFO}

Received: 15 Jun. 2020

Accepted: 30 Jul. 2020

\begin{abstract}
Objective: Radiation workers in nuclear Medicine institute are handling unsealed radioactive materials for diagnostic and therapeutic procedures of patients and thus radiation hazard on workers and public health in nuclear medicine is high comparing to other departments of the hospital. The purpose of the study is to evaluate the radiation hazard on workers and public at the indoor places of the Institute of Nuclear Medicine \& Allied Sciences (INMAS) Mitford, Sir Salimullah Medical College and Hospital Campus based on the real-time radiation monitoring data. Methods: The radiation monitoring was performed using a real-time portable digital radiation monitoring device. This real-time digital portable radiation monitoring device meets all European CE standards as well as the American "FCC 15 standard". The portable digital radiation monitoring device was placed at 1 meter above the ground on tripod and data acquisition time for each monitoring point (MP) was 1 hour. 24 MPs were selected for collection of radiation dose rates at different indoor locations of INMAS, Mitford hospital from MayJune 2019. The real-time dose rate also monitored at 1 meter distance from injected patients in the patient's waiting room after injecting 99mTc \& 131I. Results: The measured dose rates were ranged from $0.181 \pm 0.057$ $\mu$ Sv.h- 1 to $2.247 \pm 0.685 \mu$ Sv.h- 1 with an average of $0.463 \pm 0.695 \mu$ Sv.h- 1 . The annual effective dose to the radiation worker and public were varied from $0.279 \pm 0.089 \mathrm{mSv}$ to $3.481 \pm 1.061 \mathrm{mSv}$ with an average of 0.717 $\pm 1.077 \mathrm{mSv}$. Excess life-time cancer risk (ELCR) of worker and public were evaluated based on annual effective dose and varied from $1.113 \times 10-3$ to 1.385 X 10-2. Conclusion: Real-time radiation monitoring at indoor places of nuclear medicine facilities are required for detection of contamination in the workplace. So this study is needed to keep the indoor environment free from radiation hazard and thereby improving the worker and public health.
\end{abstract}

Keywords: indoor, ionizing radiation, nuclear medicine, in-situ, occupational health

\section{INTRODUCTION}

Ionizing radiation is being widely used in the hospital for diagnostic and therapeutic procedures of patients. United Nations Scientific Committee on the Effects of Atomic Radiation (UNSCEAR, 2008) estimated that there are about four billion radiographic examinations performed each year by medical Staff using ionizing radiation for diagnostic and therapeutic purposes involving to radiation worker and public health hazard if radiation protection \& safety guidelines are not properly practicing (Fazel et al., 2009). Radiation worker in the nuclear medicine institutes are always receiving small amount of ionizing radiation in the workplace while handling radioactive substances in spite of using personal radiation protective equipments (Dobrzyn'ska et al., 2014; Fazel et al., 2009). The origin of the natural radioactivity of construction materials to be known for the estimation of population exposure to radiation, because the majority of the population spends approximately $80 \%$ of their time in the indoor environment (UNSCEAR, 2008). Radiation worker in the nuclear medicine institute used to handle unsealed radioactive substances for diagnostic and therapeutic procedures of patients. Hence, the probability of getting contamination in the indoor environment of the nuclear medicine institute is more than other departments of the hospital. Overexposure and uncontrolled exposure to ionizing radiation are most important factors causing cancer and genetic mutations (Borgen et al., 2014; Bouraoui et al., 2013; Hricak et al., 2011). So, real-time radiation monitoring in the indoor environment during working time is very important for minimizing the contamination in the indoor environment and thereby keeping the radiation dose to worker and public as low as possible. The medical applications of ionizing radiation, while offering great benefit to patients, also contribute significantly to radiation exposure of worker and public (UNSCEAR, 2000; EURATOM, 
1997; UNSCEAR, 1993). Radiation worker and public exposure to ionizing radiation due to diagnostic and therapeutic procedures has increased sharply in recent years (NCRP, 2009; UNSCEAR, 2008). Among the medical staff, those primarily getting more radiation exposure are nuclear medicine staff. Radiation worker in the nuclear medicine institute used to handle unsealed radioactive substances that contribute to external and internal radiation exposure to radiation worker. The quantity of radiation exposure to worker depends on radionuclide, activity and type of procedure within a department. Significant number of medical procedures involving beta particle emitting radionuclides, extremity e.g., fingers of hand exposures and probable skin contamination of nuclear medicine worker is great concern. While performing clinical nuclear medicine procedures, the quantity of radiation exposure to worker depends on the proper handling of the radioactive substances, e.g., proper wearing of the personnel protective equipments (PPEs) namely, lead apron, hand gloves, lead glass, socks, shoes, etc. and the proper syringe shields to be used when administering radiopharmaceuticals. Radiation worker (Technologists, Technician, nurses) have to be close contact with the patient during administering radiopharmaceuticals, positioning the patient and the camera. Generally, the imaging procedures contribute the highest radiation exposure to worker (Barrall et al., 1976). Internal radiation exposures to worker are much lower than external radiation exposures and are reduced by monitoring working surfaces and airborne concentrations (NCRP, 1990). Due to the possibility of getting internal radiation exposure, higher values of annual effective dose are anticipated for worker involving in the preparation and assay of radiopharmaceuticals than for medical doctors and nurses in the nuclear medicine institute. The meaning of radiation monitoring is to control the dose accumulation pattern of individual (UNSCEAR, 1982) includes a programme of measurements, estimations and record keeping of radiation exposure to worker. The aim of the present study is to evaluate the radiation hazard on worker and public health based on the real-time radiation monitoring data of INMAS Mitford Hospital following In-Situ method. Real-time radiation monitoring at indoor environment of the nuclear medicine institute is crucial for minimizing the radiation hazard on worker \& public and thereby to keep the radiation dose to worker and public as low as possible.

\section{MATERIALS AND METHODS}

\section{Description of the Equipment}

A real-time DPRMD was used for this study. The DPRMD is German designed and manufactured, built with a solid Novadur exterior. An optional stylish leather holster with belt strap can further protect the DPRMD from the elements. The DPRMD meets all European CE standards as well as US FCC 15. All units come with an industry leading 2-year manufacturer's warranty and a serialized test certificate. The DPRMD is a fully featured Geiger counter with a form fitting ergonomic shape. The unit has a battery indicator, multiple unit conversion, real-time dose rate and cumulative dose display functions and programmable logging and alert functions. Advanced functions include PC data download via USB cable and an ultra low current power circuit for extended battery life. The DPRMD accurately measures dose rate within the range of 0.01-5000 $\mathrm{SSv} / \mathrm{hr}$ (User Manual-GAMMA SCOUT, 2014).

\section{Calibration of the Equipment}

The DPRMD was calibrated inbuilt by the manufacturer. The DPRMD is also calibrated using the gamma-ray standard sources such as ${ }^{137} \mathrm{Cs},{ }^{60} \mathrm{Co}$, etc. and X-ray Unit at the Secondary Standard Dosimetry Laboratory (SSDL) under the Bangladesh Atomic Energy Commission (BAEC). The SSDL of BAEC has been available since 1991, which is traceable to the Primary Standard Dosimetry Laboratory (PSDL) of National Physical Laboratory (NPL), UK. The SSDL of BAEC has X-ray Unit (30 $\mathrm{kV}-225 \mathrm{kV}$ ) which is needed for calibration of the radiation monitoring equipments. The performance of BAEC's SSDL has been kept as per requirements of the International Atomic Energy Agency (IAEA)/World Health Organization (WHO) network of SSDLs. Hence, the real-time radiation monitoring data of DPRMD meets up the International monitoring system.

\section{Description of the Monitoring Site}

The MPs were marked out using GARMIN eTrex HC series personal navigator. The unit uses the proven performance of Garmin high-sensitivity GPS and full-featured mapping to create an unsurpassed portable GPS receiver (Owner's ManualGARMIN eTrex HC Series, 2007). The GPS reading of the MPs were ranged from E: $90^{\circ} 40.022^{\prime}$ to E: $090^{\circ} 40.108^{\prime}$ and from N: $23^{\circ} 71.206^{\prime}$ to $N$ : $23^{\circ} 71.283^{\prime}$. Twenty four MPs were selected in the indoor environment for collection of the real-time radiation dose rates at the INMAS Mitford, Sir Salimullah Medical College and Hospital Campus following In-Situ Method. The MPs include hot lab, thyroid lab, gamma camera lab/SPECT-CT lab, RIA lab, patient waiting rooms, visitor waiting rooms, common spaces, corridors, etc. The real-time radiation monitoring was performed from May-June 2019 using the DPRMD. For each MP, the real-time DPRMD was placed on tripod at $1 \mathrm{~m}$ height and the real-time dose rate monitoring time was 1 hour. The brief description of the MPs are depicted in Table 1. The MPs were marked out using Global Positioning System (GPS) navigation. INMAS Mitford Hospital is an institute of Bangladesh Atomic Energy Commission (BAEC) under the Ministry of Science \& Technology, Government of Bangladesh. The INMAS Mitford hospital is situated in the campus of Sir Salimullah Medical College and Mitford Hospital which is the oldest medical hospital in Dhaka and also in the country.

\section{Annual Effective Dose and ELCR Estimation}

The indoor occupancy factor of public is 0.80 (UNCEAR, 1988). This occupancy factor is the fraction of the total time during which a person is exposed to a radiation field at indoor. The indoor annual effective dose to public due to radiation is estimated according to the following equation:

$$
\begin{aligned}
& \text { Annual effective dose }(\mu \mathrm{Sv}) \\
& =\text { dose rate }\left(\mu \mathrm{Sv} \cdot \mathrm{hr}^{-1}\right) \times 0.8 \\
& \times 8760 \mathrm{hr} \cdot \mathrm{yr}^{-1}
\end{aligned}
$$

Excess life-time cancer risk (ELCR) is estimated using the following equation: 


$$
E L C R=A E D \times D L \times R F
$$

Where AED is the annual effective dose to radiation worker and public, DL is the duration of life of Bangladeshi people (http://en.worldstat.info/Asia/Bangladesh, 2019) and RF is the risk factor $\left(\mathrm{Sv}^{-1}\right)$, it is a fatal cancer risk per Sievert. For stochastic effects from low-dose radiation, ICRP 103 suggested the value of 0.057 for the public exposure (ICRP, 2007).

\section{RESULTS AND DISCUSSION}

The measured mean annual effective dose for radiation worker was $0.717 \mathrm{mSv}$ which is lower than the worldwide average annual effective dose $(1.4 \mathrm{mSv})$ for radiation worker in nuclear medicine (UNSCEAR, 2008). The maximum radiation dose for one day in SPECT-CT room at INMAS Mitford hospital was $14.38 \mu \mathrm{Sv}$ which is lower than the maximum allowable radiation dose for one day $(55 \mu \mathrm{Sv})$ in nuclear medicine institute (ICRP, 2008). The mean annual effective dose for radiation worker at nuclear medicine institutes in Greece during the period 2000-2002 was ranged from 0.75-1.49 mSv (UNSCEAR, 2008). The mean annual effective dose to radiation worker for different indoor environment of INMAS Mitford hospital was remained within the radiation dose range of nuclear medicine institutes in Greece except SPECT-CT Lab. Taking the conversion factor of $0.7 \mathrm{~Sv} \mathrm{~Gy}^{-1}$ as suggested by UNSCEAR (UNSCEAR, 2000) and taking into account that public in Bangladesh spend about $20 \%$ of their time outdoor and remaining $80 \%$ of time indoor; the annual effective dose of worker and public of INMAS Mitford Hospital campus in Dhaka city were estimated and depicted in Table 1.

Table 1. Annual effective dose of worker and public due to radiation at indoor environment of INMAS Mitford Hospital

\begin{tabular}{|c|c|c|c|c|c|c|}
\hline \multirow{2}{*}{ Sl. No. } & \multirow{2}{*}{ Name of Place } & \multirow{2}{*}{$\begin{array}{l}\text { Latitude/ } \\
\text { Altitude }\end{array}$} & \multicolumn{3}{|c|}{ Radiation dose rate $(\mu \mathrm{Sv} / \mathrm{hr})$} & \multirow{2}{*}{$\begin{array}{l}\text { Annual effective dose due to } \\
\text { radiation }(\mathrm{mSv}) \pm \mathrm{SD}\end{array}$} \\
\hline & & & Range & Mean & SD & \\
\hline 1. & Gamma camera lab & $\begin{array}{l}\mathrm{N} 23^{\circ} 42.765 \\
\mathrm{E} 90^{\circ} 24.032\end{array}$ & $0.970-1.810$ & 1.323 & 0.203 & $2.049 \pm 0.315$ \\
\hline 2. & Thyroid lab & $\begin{array}{l}\mathrm{N} 23^{\circ} 42.733 \\
\mathrm{E} 90^{\circ} 24.023\end{array}$ & $0.840-2.600$ & 1.502 & 0.389 & $2.327 \pm 0.603$ \\
\hline 3. & RIA lab & $\begin{array}{l}\mathrm{N} 23^{\circ} 42.733 \\
\mathrm{E} 90^{\circ} 24.034\end{array}$ & $0.100-0.260$ & 0.195 & 0.043 & $0.302 \pm 0.068$ \\
\hline 4. & SPECT-CT lab & $\begin{array}{l}\mathrm{N} 23^{\circ} 42.753 \\
\mathrm{E} 90^{\circ} 24.038\end{array}$ & $0.169-3.360$ & 2.247 & 0.685 & $3.481 \pm 1.061$ \\
\hline 5. & $\begin{array}{l}\text { Visitor/patient waiting room-1 } \\
\text { ground floor }\end{array}$ & $\begin{array}{l}\mathrm{N} 23^{\circ} 42.738 \\
\mathrm{E} 90^{\circ} 24.018\end{array}$ & $0.100-0.510$ & 0.289 & 0.108 & $0.449 \pm 0.168$ \\
\hline 6. & $\begin{array}{l}\text { Visitor/patient waiting room-3 ground } \\
\text { floor }\end{array}$ & $\begin{array}{l}\mathrm{N} 23^{\circ} 42.733 \\
\mathrm{E} 90^{\circ} 24.023\end{array}$ & $0.130-4.730$ & 0.798 & 1.339 & $1.235 \pm 2.073$ \\
\hline 7. & $\begin{array}{c}\text { Ground floor } \\
\text { Counter }\end{array}$ & $\begin{array}{l}\mathrm{N} 23^{\circ} 42.728 \\
\mathrm{E} 90^{\circ} 24.012\end{array}$ & $0.050-0.320$ & 0.212 & 0.056 & $0.328 \pm 0.087$ \\
\hline 8. & Ground space & $\begin{array}{l}\mathrm{N} 23^{\circ} 42.764 \\
\mathrm{E} 90^{\circ} 24.028\end{array}$ & $0.070-0.300$ & 0.181 & 0.057 & $0.279 \pm 0.089$ \\
\hline 9. & $\begin{array}{l}\text { Ground floor } \\
\text { South side }\end{array}$ & $\begin{array}{l}\mathrm{N} 23^{\circ} 42.723 \\
\mathrm{E} 90^{\circ} 24.028\end{array}$ & $0.180-4.710$ & 1.426 & 1.666 & $2.208 \pm 2.581$ \\
\hline 10. & $\begin{array}{l}\text { Visitor/patient waiting room-1 } \\
\qquad 1^{\text {st }} \text { floor }\end{array}$ & $\begin{array}{l}\mathrm{N} 23^{\circ} 42.747 \\
\mathrm{E} 90^{\circ} 24.025\end{array}$ & $0.120-0.250$ & 0.189 & 0.033 & $0.292 \pm 0.052$ \\
\hline 11. & Visitor/patient waiting room-2 $1^{\text {st }}$ floor & $\begin{array}{l}\mathrm{N} 23^{\circ} 42.739 \\
\mathrm{E} 90^{\circ} 24.038\end{array}$ & $0.130-0.270$ & 0.205 & 0.035 & $0.318 \pm 0.054$ \\
\hline 12. & Visitor/patient waiting room-3 $1^{\text {st }}$ floor & $\begin{array}{l}\mathrm{N} 23^{\circ} 42.739 \\
\mathrm{E} 90^{\circ} 24.014\end{array}$ & $0.020-0.320$ & 0.192 & 0.064 & $0.298 \pm 0.099$ \\
\hline 13. & $1^{\text {st }}$ floor south side & $\begin{array}{l}\mathrm{N} 23^{\circ} 42.739 \\
\mathrm{E} 90^{\circ} 24.026\end{array}$ & $0.100-0.280$ & 0.200 & 0.045 & $0.310 \pm 0.071$ \\
\hline 14. & $1^{\text {st }}$ floor north side & $\begin{array}{l}\mathrm{N} 23^{\circ} 42.764 \\
\mathrm{E} 90^{\circ} 24.041\end{array}$ & $0.130-0.260$ & 0.196 & 0.037 & $0.304 \pm 0.057$ \\
\hline 15. & $1^{\text {st }}$ floor common space & $\begin{array}{l}\mathrm{N} 23^{\circ} 42.729 \\
\mathrm{E} 90^{\circ} 24.023\end{array}$ & $0.070-0.310$ & 0.221 & 0.054 & $0.343 \pm 0.084$ \\
\hline 16. & $2^{\text {nd }}$ floor south side & $\begin{array}{l}\mathrm{N} 23^{\circ} 42.728 \\
\mathrm{E} 90^{\circ} 24.025\end{array}$ & $0.050-0.360$ & 0.203 & 0.069 & $0.315 \pm 0.107$ \\
\hline 17. & $2^{\text {nd }}$ floor north side & $\begin{array}{l}\mathrm{N} 23^{\circ} 42.733 \\
\mathrm{E} 90^{\circ} 24.038\end{array}$ & $0.100-0.270$ & 0.188 & 0.045 & $0.291 \pm 0.071$ \\
\hline 18. & $2^{\text {nd }}$ floor common space & $\begin{array}{l}\mathrm{N}^{2} 3^{\circ} 42.729 \\
\mathrm{E} 90^{\circ} 24.025\end{array}$ & $0.070-0.270$ & 0.193 & 0.051 & $0.299 \pm 0.080$ \\
\hline 19. & $1^{\text {st }}$ floor common space & $\begin{array}{l}\mathrm{N} 23^{\circ} 42.746 \\
\mathrm{E} 90^{\circ} 24.030\end{array}$ & $0.100-0.280$ & 0.218 & 0.041 & $0.337 \pm 0.064$ \\
\hline 20. & $3^{\text {rd }}$ floor north side & $\begin{array}{l}\mathrm{N}^{2} 3^{\circ} 42.729 \\
\mathrm{E} 90^{\circ} 24.027\end{array}$ & $0.090-0.300$ & 0.198 & 0.055 & $0.307 \pm 0.086$ \\
\hline 21. & $3^{\text {rd }}$ floor south side & $\begin{array}{l}\mathrm{N}^{2} 3^{\circ} 42.728 \\
\mathrm{E} 90^{\circ} 24.025\end{array}$ & $0.130-0.250$ & 0.185 & 0.033 & $0.287 \pm 0.052$ \\
\hline 22. & $3^{\text {rd }}$ floor east side & $\begin{array}{l}\mathrm{N}^{2} 3^{\circ} 42.734 \\
\mathrm{E} 90^{\circ} 24.024\end{array}$ & $0.050-0.270$ & 0.189 & 0.052 & $0.292 \pm 0.082$ \\
\hline 23. & Common space $3^{\text {rd }}$ floor & $\begin{array}{l}\mathrm{N}^{2} 3^{\circ} 42.733 \\
\mathrm{E} 90^{\circ} 24.024\end{array}$ & $0.120-0.270$ & 0.194 & 0.045 & $0.301 \pm 0.069$ \\
\hline 24. & Common space $3^{\text {rd }}$ floor & $\begin{array}{l}\mathrm{N}^{2} 3^{\circ} 42.745 \\
\mathrm{E} 90^{\circ} 24.033\end{array}$ & $0.140-0.290$ & 0.215 & 0.046 & $0.333 \pm 0.071$ \\
\hline
\end{tabular}


Table 2. Comparison of dose rate and annual effective dose in the indoor environment of INMAS Mitford Hospital with other countries

\begin{tabular}{|c|c|c|c|c|c|}
\hline $\begin{array}{c}\text { Name of indoor place of } \\
\text { hospital }\end{array}$ & $\begin{array}{c}\text { Range } \\
(\mu \mathrm{Sv} / \mathrm{hr})\end{array}$ & $\begin{array}{l}\text { Mean dose rate } \\
(\mu \mathrm{Sv} / \mathrm{hr})\end{array}$ & $\begin{array}{c}\text { Annual range/Mean annual } \\
\text { effective dose (mSv) }\end{array}$ & Country & Reference \\
\hline Kwali General Hospital & $0.100-0.124$ & $0.107 \pm 0.003$ & $0.750 \pm 0.020$ & Nigeria & James et al. (2015) \\
\hline Skane radiodiagnostic centre & - & - & 2.063 & Nigeria & Jwanbot et al. (2012) \\
\hline $\begin{array}{c}\text { Plateau state specialized } \\
\text { hospital }\end{array}$ & - & - & 2.443 & Nigeria & Jwanbot et al. (2012) \\
\hline $\begin{array}{c}\text { Braithwaite memorial } \\
\text { specialized hospital (x-ray } \\
\text { department) }\end{array}$ & $0.140-0.160$ & $0.146 \pm 0.02$ & - & Nigeria & Okoye and Avwiri (2013) \\
\hline $\begin{array}{c}\text { Braithwaite memorial } \\
\text { specialized hospital (in wards) }\end{array}$ & $0.12-0.19$ & $0.136 \pm 0.02$ & - & Nigeria & Okoye and Avwiri (2013) \\
\hline $\begin{array}{c}\text { Woliso hospital } \\
\text { (control room;waiting room; } \mathrm{x}^{-} \\
\text {ray room) }\end{array}$ & $\begin{array}{c}0.10-0.15 \\
0.136-0.141 \\
0.13-0.147 \\
\end{array}$ & $0.136 \pm 0.01$ & - & Ethiopia & Geletu et al. (2017) \\
\hline $\begin{array}{c}\text { Butajera hospital } \\
\text { (control room;waiting room; x- } \\
\text { ray room) }\end{array}$ & $\begin{array}{c}0.07-0.13 \\
0.12-0.15 \\
0.105-0.172 \\
\end{array}$ & $0.14 \pm 0.02$ & - & Ethiopia & Geletu et al. (2017) \\
\hline $\begin{array}{c}\text { Mercy hospital } \\
\text { (control room;waiting room;x- } \\
\text { ray room) }\end{array}$ & $\begin{array}{c}0.033-0.017 \\
0.10-0.10 \\
0.10-0.15\end{array}$ & $0.14 \pm 0.01$ & - & Ethiopia & Geletu et al. (2017) \\
\hline $\begin{array}{c}\text { Atat hospital } \\
\text { (control room; waiting room;x- } \\
\text { ray room) }\end{array}$ & $\begin{array}{c}0.117-0.158 \\
0.08-0.13 \\
0.13-0.85 \\
\end{array}$ & $0.148 \pm 0.03$ & - & Ethiopia & Geletu et al. (2017) \\
\hline $\begin{array}{c}\text { Gaza Strip hospital } \\
\text { CT scan room control panel; } \\
\text { corridors; patient waiting room }\end{array}$ & 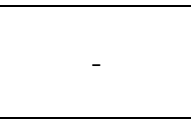 & - & $\begin{array}{l}5.9-14.2 \\
6.3-12.3 \\
0.8-13.2 \\
\end{array}$ & Palestine & Abu Zer et al. (2016) \\
\hline $\begin{array}{l}\text { Teaching Sohag Hospital Linear } \\
\text { accelerator;CT;X-ray }\end{array}$ & $\begin{array}{c}0.094-4.30 \\
0.084-12.528 \\
0.076-0.15\end{array}$ & $0.10 \pm 0.023$ & $\begin{array}{c}0.659-30.134 \\
0.589-87.796 \\
0.533-1.051\end{array}$ & Egypt & Harb (2016) \\
\hline $\begin{array}{l}\text { INMAS Mitford Hospital } \\
\text { Visitor \&Patient waiting room; } \\
\text { common space/corridors }\end{array}$ & $\begin{array}{c}0.02-4.73 \\
0.05-4.71\end{array}$ & $\begin{array}{c}0.335 \pm 0.638 \\
0.282 \pm 525\end{array}$ & $\begin{array}{c}0.031-7.32 / 0.518 \pm 0.988 \\
0.077-7.29 / \\
0.436 \pm 0.813\end{array}$ & Bangladesh & This study \\
\hline
\end{tabular}

Table 2 shows the indoor dose rate and annual effective dose of worker and public of INMAS Mitford Hospital and those values are compared with other countries. From Table 2, it can be seen that the real-time radiation dose rate and estimated annual effective dose at CT room of INMAS Mitford Hospital is lower than those of Teaching Sohag Hospital in Egypt (Harb, 2016) and Gaza Strip Hospital in Palestine (Abu Zer et al., 2016).

The amount of radioisotopes are injected into the adult patients for gamma camera or Computed Tomography (CT) imaging: for bone scan $10-20 \mathrm{mCi}^{99 \mathrm{~m}} \mathrm{Tc}$, for DTPA 3-5 $\mathrm{mCi}^{99 \mathrm{~m}} \mathrm{Tc}$, for DMSA 4-5 mCi ${ }^{99 \mathrm{~m}} \mathrm{Tc}$, for thyroid uptake $5-10$ $\mathrm{mCi}^{131} \mathrm{I}$ and for thyroid scan $2 \mathrm{mCi}^{99 \mathrm{~m}} \mathrm{Tc}$. Real-time radiation dose rates of patient's waiting room were measured at 1 meter distance from the radioisotope injecting patients in the INMAS Mitford Hospital from May-June 2019. The radiation dose rates were monitored using the DPRMD. The measured dose rates were ranged from $13.420 \mu \mathrm{Sv} \cdot \mathrm{h}^{-1}$ to $17.690 \mu \mathrm{Sv} \cdot \mathrm{h}^{-1}$ with an average of $15.182 \pm 1.169 \mu \mathrm{Sv} \cdot \mathrm{h}^{-1}$. The radiation dose rate at 1 meter distance from the injecting patients who are waiting after injecting radioisotope in the waiting room for gamma camera/CT scan image (e.g., bone scan, thyroid scan, thyroid uptake) are comparable with those values of Pakistan (Javed et al., 2017) and Norway (Stenstad et al., 2014). The maximum allowable radiation dose of worker in a working day at the nuclear medicine institute is $55 \mu \mathrm{Sv}$ (ICRP, 2008). The maximum radiation dose at 1 meter distance from radioisotopes injecting patients in a working day in the INMAS Mitford was calculated and it was found to be $141.52 \mu$ Sv. From this study, it was observed that hospital staff and public entrance in the patient's waiting room after injection of radioisotopes have to be restricted in order to keep their radiation dose within the allowable limit. In addition to that radiation worker has to handle the radioactive substances and radiation generating equipments in the nuclear medicine institute as per the radiation protection and safety regulations of Bangladesh as well as international body recommendations during their daily work. Figure 1 shows the frequency distribution of radiation dose rate at indoor environment of INMAS Mitford Hospital. From Figure 1, it is observed that the real-time radiation dose rate of 19 indoor locations remained within the range of $0.10-0.50 \mu \mathrm{Sv} / \mathrm{hr}$ out of 24 indoor locations.

Figure 2 shows the mean annual effective dose in the indoor environment of each monitoring point was normalized to the minimum annual effective dose. From Figure 2, it can be seen that the difference of the mean annual effective dose of few monitoring locations are high. The reason for this high variation of mean annual effective dose for few indoor environment are that the different type of radiation generating equipments and different type of radioisotopes are handling/stored in the different laboratory of the INMAS Mitford Hospital.

The ELCR of medical staff and the public in the indoor environment of INMAS Mitford Hospital campus varied from 


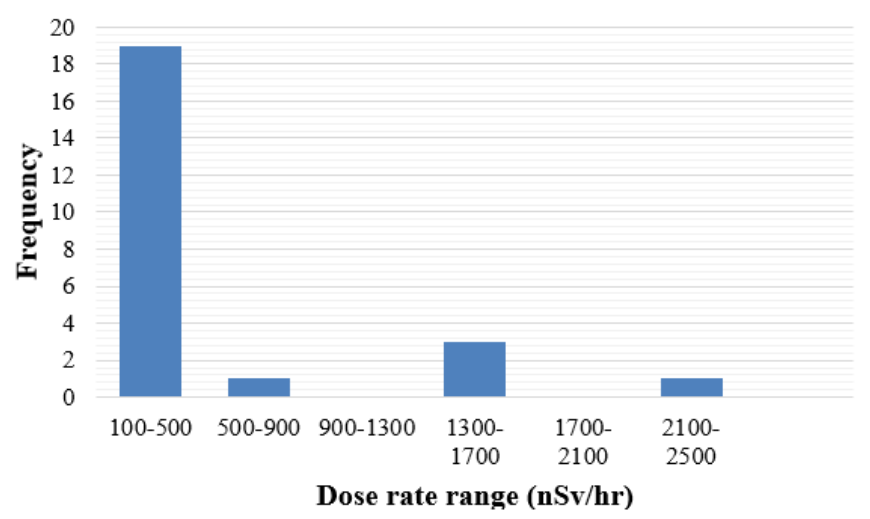

Figure 1. Frequency distribution of radiation dose rate at indoor environment of INMAS Mitford Hospital

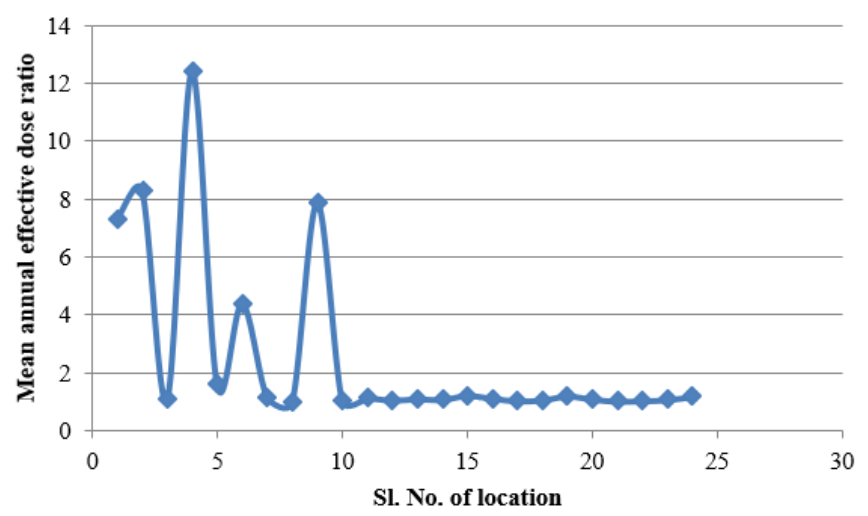

Figure 2. Mean annual effective dose value of each MP normalized to the minimum annual effective dose in the indoor environment

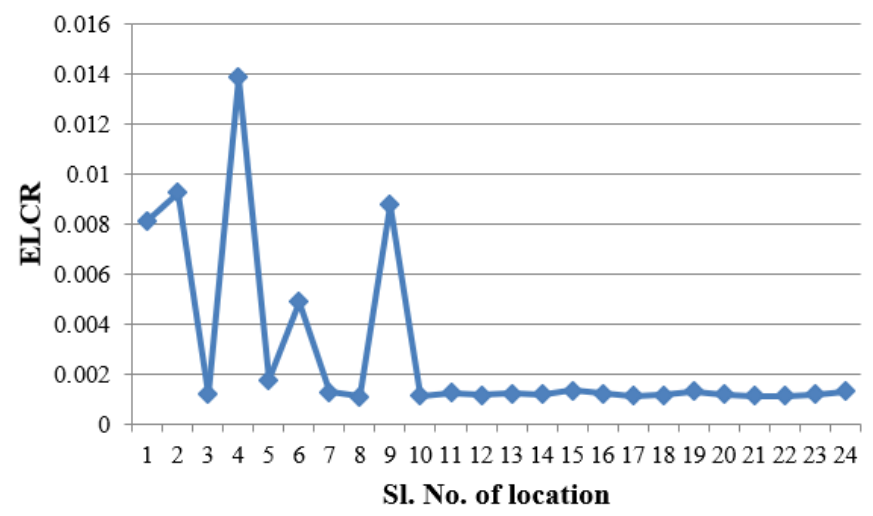

Figure 3. ELCR of radiation worker and the public at indoor environment of INMAS Mitford hospital campus

$1.113 \times 10^{-3}$ to $1.385 \times 10^{-2}$ with an average value of $2.867 \times 10^{-}$ ${ }^{3}$.The estimation of ELCR of medical staff and the public is based on the calculated annual effective dose in the indoor environment of various rooms and corridors/common spaces. From Figure 3, it can be seen that the variation of ELCR of medical staff and the public is high for few indoor locations. The reason is that radiation worker handles different type of radioactive substances and radiation generating equipments for diagnostic and therapeutic purposes that contributed to different exposure to worker and the public.

Usually, effective radiation dose for CT procedure is higher than other diagnostic imaging modalities (Wall and Hart,
1997) and this study found similar finding. It is mentioned in the Swedish Radiation Safety Authority report that CT and nuclear medicine took $16 \%$ of all radiological investigations except mammography and contributed to $64 \%$ of the collective radiation dose in Sweden in 2005 (Almen, A. et al., 2008) . It is found in the National Council on Radiological Protection and Measurement in USA, CT and nuclear medicine took $22 \%$ of all radiological investigations but contributed to $75 \%$ of the collective radiation dose in US in 2006 (NCRP, 2009). Nevertheless, the radiation dose depends on the number of manipulations, the radioisotope types and the quantity of activity handling.

The mean excess life-time cancer risk (ELCR) of worker and public of INMAS Mitford Hospital is lower than the world average value of $5.57 \times 10^{-3}$ (UNSCEAR, 2008) that need further research for verification. Even though the annual effective dose and ELCR values at indoor environment of INMAS Mitford hospital are lower than the world average value except SPECT-CT lab but all the values are much lower the radiation dose limit set for the radiation worker in the Nuclear Safety and Radiation Control Rules-1997 of Bangladesh (NSRC Rules, 1997). The estimated mean annual effective dose of $0.717 \mathrm{mSv}$ is not expected to contribute considerable additional radiation hazard on worker and public health as per the radiological health hazard consideration. It may be mentioned here that the annual dose limit of public is $1 \mathrm{mSv}$ and this dose limit is related to practices from planned exposure situations (e.g., nuclear installations or hospitals) and is not related to the radiation dose getting from existing exposure situations (e.g., natural sources of radiation) as per recommendations of the ICRP 103 (ICRP, 2007). The real-time radiation monitoring in the indoor environment of the hospital especially nuclear medicine institutes have to be performed regularly for the safety of the worker, public and the environment and keeping the indoor environment free from unnecessary radiation.

\section{CONCLUSION}

Medical staff used to handle unsealed radioactive substances and radiation generating equipments in the nuclear medicine institute for diagnostic and treatment purposes of patients. So, the probability of getting contamination in the indoor environment of the nuclear medicine institute is more than other departments of the hospital. For that reason, real-time radiation monitoring during working time in the indoor environment of the hospital is very important for the detection of contamination and consequently minimizing the radiation hazard on worker \& public is possible and keeping the indoor environment of the hospital free from radiation hazard. The real-time measured dose rates in the indoor environment were ranged from 0.181 $\pm 0.057 \mu \mathrm{Sv} . \mathrm{h}^{-1}$ to $2.247 \pm 0.685 \mu \mathrm{Sv} \cdot \mathrm{h}^{-1}$ with an average of 0.463 $\pm 0.695 \mu \mathrm{Sv} \cdot \mathrm{h}^{-1}$. The estimated annual effective dose to the radiation worker and the public in the indoor environment were found to be in the range of $0.279 \pm 0.089 \mathrm{mSv}$ to $3.481 \pm$ $1.061 \mathrm{mSv}$ with an average of $0.717 \pm 1.077 \mathrm{mSv}$. Application of CT in medicine tremendously improved the medical imaging, but CT contributed more radiation exposure to radiation worker and the public. Hence, periodic education and training 
of radiation worker is required for proper handling of the radioactive substances as well as radiation generating equipments in the nuclear medicine institute in order to minimize the radiation hazard on worker and public health and to keep the indoor environment free from radiation hazard.

\section{ACKNOWLEDGEMENT}

This research is funded by the Ministry of Science and Technology, Government of Bangladesh under the Special Research Allocation Project 2019-2020.

\section{REFERENCES}

Almén, A., Richter, S. and Leitz, W. (2008). Number of radiological examinations in Sweden. Swedish Radiation Protection Authority Report, 3 (in Swedish). Available at: https://inis.iaea.org/collection/NCLCollectionStore/_Publi c/39/043/39043574.pdf?r=1

Barrall, R. C., et al. (1976). Personnel radiation exposure and protection from $99 \mathrm{mTc}$ radiations in: Biophysical aspects of the medical use of technetium-99m, Kereiakes, J. G. and Corey, K. R. (eds.), AAPM Monograph No. 1. American Institute of Physics (p.77), New York.

Borgen, L. and Stranden, E. (2014). Radiation knowledge and perception of referral practice among radiologists and radiographers compared with referring clinicians. Insights into Imaging, 5, 635-640. Available at: https://link. springer.com/article/10.1007/s13244-014-0348-y

Bouraoui, S., Mougou, S., Drira, A., Tabka, F., Bouali, N., Mrizek, N., Elghezal, H. and Saad, A. (2013). Cytogenetic approach to the effects of low levels of ionizing radiation (IR) on the exposed Tunisian hospital workers. Int J. Occup. Med. Environ. Health, 26(1), 144-154. https://doi.org/ 10.2478/s13382-013-0084-4

EURATOM (1997). Council directive 97/43, on health protection of individuals against the dangers of ionizing radiation in relation to medical exposure, and repealing Directive 84/466/Euratom. Official Journal of the European Communities, L 180/22. Available at: https://eurlex.europa.eu/legalcontent/en/TXT/?uri=CELEX\%3A3199 7L0043 (Accessed: 17 July 2020).

Fazel, R., Krumholz, H. M., Wang, Y., Ross, J. S., Chen, J., Ting, H. H. ... Nallamothu, B. K. (2009). Exposure to low-dose ionizing radiation from medical imaging procedures. $N$. Engl. J. Med., 361(9), 849-857. https://doi.org/10.1056/ NEJMoa0901249

Geletu, G. M., Abiko, F. and Sahlu, S. (2017). Implementation of a radiation protection system at four hospitals in Ethiopia. J. Radiol. Radiat. Ther., 5(1), 1069. Available at: https://arxiv.org/ftp/arxiv/papers/1905/1905.07271.pdf

Harb, S. (2016). Evaluation of radiation doses and radiation risk in Teaching Sohag Hospital, Egypt. Journal of Nuclear and Particle Physics, 6(4), 88-93. https://doi.org/ 10.5923/j.jnpp.20160604.03
Hricak, H., Brenner, D. J., James Adelstein, S., Frush, D. P., Hall, E. J., Howell, R. W.... Wagner, L. K. (2011). Managing radiation use in medical imaging: a multi-faceted challenge. Radiology, 258(3), 889-905. https://doi.org/ 10.1148/radiol.10101157

ICRP (2007). Recommendations of the ICRP: Annals of the ICRP (International Commission on Radiological Protection), 37, 2-4 (Ottawa, Ontario, Canada). Available at: https://www.icrp.org/page.asp?id=7

ICRP (2008). Radiation Dose to Patients from Radiopharmaceuticals - Addendum 3 to ICRP Publication 53, ICRP Publication 106, Ann. ICRP 38, 1-2 (Ottawa, Ontario, Canada). Available at: https://www.icrp.org/page. asp?id=7

Information about Bangladesh (2019). Available at: http://en.worldstat.info/Asia/Bangladesh (Accessed: 30 August 2019).

James, I. U., Moses, I. F., Vandi, J. N. and Ikoh, U. E. (2015). Measurement of indoor and outdoor background ionizing radiation levels of Kwali General Hospital, Abuja. J. Appl. Sci. Environ. Manage., 19(1), 89-93. https://doi.org/ 10.4314/jasem.v19i1.12

Jwanbot, D. I., Izam, M. M., Nyam, G. G. and Agada, I. S. (2012). Evaluation of indoor background ionizing radiation profile in some hospitals in Jos Plateau state, Nigeria. Journal of Natural Sciences Research, 2(7), 35-40. https://doi.org/ 10.7176/JNSR

Stenstad, L.-I., Pedersen, G. A., Landmark, A. D. and Brattheim, B. (2014). Nuclear radiation dose to the surroundings from patients who are undergoing nuclear medicine examinations. Radiography Open, 1(1), 11-18. https://doi.org/10.7577/radopen.1196

Dobrzyn'ska, M. M., Pachocki, K. A., Gajowik, A., Radzikowska, J. and Sackiewicz, A. (2014). The effect of occupational exposure to ionizing radiation on the DNA damage in peripheral blood leukocytes of nuclear medicine personal. J. Occup. Health, 56(5), 379-386. https://doi.org/ 10.1539/joh.13-0287-OA

Javed, M., Ur Rahman, S., Tanveer, I., Asghar, G., Fatima, S. and Fahim, M. (2017). Measurement of radiation doses to occupational workers in nuclear medicine. Pakistan Journal of Nuclear Medicine, 7(1), 16-19. https://doi.org/ 10.24911/PJNMED.7.3

NCRP (1990). National Council on Radiation Protection and Measurements. Implementation of the principle of as low as reasonably achievable (ALARA) for medical and dental personnel. NCRP Report No. 107, (Bethesda, USA). Available at: https://ncrponline.org/

NSRC (1997). The Nuclear Safety and Radiation Control (NSRC) Rules of Bangladesh (SRO No. 205-Law/97).

Okoye, P. C. and Avwiri, G. O. (2013). Evaluation of background ionizing radiation levels of Braithwaite Memorial Specialist Hospital Port Harcourt, Rivers State. Am. J. Sci. Ind. Res., 4(4), 359-365. https://doi.org/10.5251/ajsir.2013. 4.4.359.365

Owner's Manual (2007). GARMIN eTrex HC Series. Available at: https://static.garmincdn.com/pumac/eTrexLegendHCx _OwnersManual.pdf 
Abu Zer, S. S., Khadoura, K. J., Yassin, S. S., Al Agha, M. R. (2016). Ionizing radiation leakage in radio-diagnostic centers at Gaza Strip Hospitals, Palestine. Asian Review of Environmental and Earth Sciences, 3(1), 18-26. https://doi.org/10.20448/journal.506/2016.3.1/506.1.18.26

UNSCEAR (2000). United Nations Scientific Committee on the Effects of Atomic Radiation. Sources and Effects of Ionizing Radiation Report to General Assembly, with Scientific Annexes (New York: United Nations, United Nations Sales Publication E.00.IX.3). Available at: https://www.unscear. org/

UNSCEAR (1993). United Nations Scientific Committee on the Effects of Atomic Radiation Sources and Effects of Ionizing Radiation Report to General Assembly, with Scientific Annexes (New York: United Nations). Available at: https://www.unscear.org/

UNSCEAR (2008). United Nations Scientific Committee on the Effects of Atomic Radiation. Sources and Effects of Ionizing Radiation. Report to General Assembly with Scientific Annexes, volume I, Annex A: Medical radiation exposures (New York: United Nations, United Nations Publication Sales No.E.10.XI.3). Available at: https://www.unscear.org/
UNSCEAR (1982). United Nations Scientific Committee on the Effects of Atomic Radiation. Ionizing radiation: sources and biological effects. United Nations Scientific Committee on the Effects of Atomic Radiation, (New York: United Nations E82. IX.8). Available at: https://www.unscear.org/

UNSCEAR (1988). United Nations Scientific Committee on the Effects of Atomic Radiation, sources, effects and risks of ionizing radiation, (United Nations, New York). Available at: https://www.unscear.org/

User Manual GAMMA SCOUT (2014). Available at: https://www.gamma-scout.com/EN/Handbuch.php

Wall, B. F. and Hart, D. (1997). Revised radiation doses for typical X-ray examinations: report on a recent review of doses to patients from medical X-ray examinations in the UK by NRPB. British Journal of Radiology, 70, 437-439. https://doi.org/10.1259/bjr.70.833.9227222 